\title{
THE RELATIONSHIP EXPERIENCES OF PROFESSIONAL NURSES WITH NURSE MAN- AGERS
}

\author{
Sindiwe Valencia James \\ M Cur \\ Lecturer, Nursing Science, University of Port Elizabeth \\ Corresponding author: sindisiwe.james@upe.ac.za
}

\author{
Wilhelmina J Kotzé \\ DCur \\ Professor, Nursing Science, University of Port Elizabeth
}

\author{
Dalena van Rooyen \\ D Cur \\ Senior Lecturer, Nursing Science, University of Port Elizabeth
}

Keywords: experiences; professional nurses; nurse managers; care standards; relationships; qualitative research

\begin{abstract}
This qualitative study was undertaken to explore and describe the experiences of professional nurses in their relationships with nurse managers. Concerns about declining nursing care standards have been expressed in radio newsbulletins, television interviews and newspapers. This decline is thought to come from the pressures brought about by rapid changes in political, socio-economic and technological spheres. It therefore became important to the researcher to acquire knowledge about the manner in which nurses support each other during these times of change. Data were collected by means of individual interviews. Interviews were audiotaped and field notes were taken to provide the researcher with complementary information. Data analysis was done using the data analysis method described by Tesch (in Creswell, 1994:155). Results revealed that professional nurses experience a breakdown in their relationships with nurse managers and that the professional nurses' expectations relating to the work environment are not being met. The experiences manifested in feelings of anger, pain and disillusionment and led to demotivation of the professional nurses. Guidelines were proposed to address the aforementioned experiences.
\end{abstract}

\section{OPSOMMING}

Hierdie kwalitatiewe studie is onderneem om die belewenisse van professionele verpleegkundiges ten opsigte van hulle verhoudings met verpleegbestuurders te verken en te beskryf. Kommer oor verpleegstandaarde wat verswak is in radio -en televisienuusberigte asook koerantberigte uitgespreek. Die agteruitgang van standaarde kan toegeskryf word aan die druk wat deur die veranderende politieke, sosio-ekonomiese en tegnologiese sfere meegebring word. Dit het daarom vir die navorser noodsaaklik geword om kennis in te win oor die wyse waarop verpleegkundiges mekaar in hierdie tye van verandering ondersteun. Data is deur middel van individuele onderhoude ingesamel. Onderhoude is op band opgeneem en veldnotas is geneem om sodoende aanvullende inligting aan die navorser te verskaf. Data analise het plaasgevind deur van Tesch se metode (in Creswell, 1994:155) gebruik te maak. Die resultate van die studie het aan die lig gebring dat professionele verpleegkundiges beleef dat hulle verhoudings met verpleegbestuurders nie na wense is nie en dat daar nie aan hulle verwagtinge ten opsigte van hulle werksomgewing voldoen word nie. Die belewenisse het gemanifesteer in gevoelens van aggressie, pyn en ontnugtering en het tot die demotivering van professionele verpleegkundiges gelei. Riglyne is voorgestel om genoemde belewenisse aan te spreek. 


\section{INTRODUCTION}

Owing to rapid changes in the political, socio-economic and technological spheres of South African life, nursing has come increasingly under pressure to improve its quality (Gmeiner \& Poggenpoel, 1996:55). As a result of this pressure and the increased health demands by the public, the need for caring, both in respect of the patient as well as the nursing personnel, has been directly affected. This has contributed to an increase in the expectations of the professional nurse regarding support from nurse managers. Pera and Van Tonder (1996:69) claim that nurses have a professional obligation to care for one another, maintain professional responsibilities such as co-operation and self-development, and provide support for one another.

Nurse managers need to take the initiative in offering support and encouraging effective relationships among nursing colleagues. Gmeiner and Poggenpoel (1996:55) state that nursing service managers who are responsible for coordinating nursing services within the health care system have an important role to play in managing change constructively and that, if this is not managed well, uncertainty and disillusionment will follow. For this reason nurse managers, by virtue of their expertise and wisdom gained through experience in nursing practice, are expected to help the professional nurse through the phase of uncertainty caused by the demands for better quality health care (Khoza, 1996:42).

It has been observed by some of the nursing personnel that the nurse managers are not fulfilling this role. In this regard Khoza (1996:42) states: "We tend to focus on caring for the patients, clients and their families; but we forget to care for ourselves and colleagues in the nursing profession". Related to this latter statement the researcher learned, for example, that a professional nurse once found herself in a crisis situation on a Monday morning when her toddler's babysitter failed to arrive for work. She telephoned her nurse manager to report that, due to the crisis, she may be either very late for work or not be able to come on duty. She was told to sort out her problem as soon as possible and come on duty, "... as the hospital would not tolerate that type of excuse". As this was her first experience of a problem of this nature she was surprised and hurt by the reaction of the nurse manager.
Holism is an enlightened approach to human caring which, according to Sourial (1997:1189) means that humans are to be considered in totality (psyche-spirit-body). Holism needs to be implemented within the leadership structure in nursing. Nurses, especially professional nurses, often feel that they have little control over situations and thus look to their nurse managers for support. Such support includes the availability of the nurse manager, creation of a stable working environment and a reduction in the amount of stress experienced by the professional nurses. Provision of support to professional nurses will lead to a closer relationship with the nurse manager and increase productivity.

\section{PROBLEM STATEMENT}

Effective relationships between professional nurses and nurse managers assist in securing holistic caring, which includes personalised health care in which relationships and personal development of both staff and patients are emphasised (Gordon, 1990:357). Since 1996 there has been an increase in bad publicity in the media with regard to both health care provision in state hospitals and the conditions under which nurses are working. Complaints raised by nurses about the lack of resources have also received attention in the local newspapers. Together with these negative reports there has been a significant increase in the number of professional nurses leaving state hospitals to take up employment either in the private sector or in other countries. The researcher found, when speaking to professional nurses who have left state hospitals for private hospitals, that the lack of resources could not be regarded as the only cause of this phenomenon. Most of the professional nurses who have left the services complained about the non-caring attitudes of nurse managers in the hospitals in which they were formerly employed. After becoming aware of this situation, the researcher decided to undertake this study in order to explore the nature of the relationship between professional nurses and nurse managers.

\section{OBJECTIVES OF THE STUDY}

The objectives of the study were to:

- explore and describe the experiences of professional nurses regarding their relationships with nurse managers; and 
- develop accompaniment guidelines to enhance the relationships between nurse managers and professional nurses.

\section{RESEARCH DESIGN}

The design for the study was qualitative, explorative, descriptive and contextual.

\section{RESEARCH METHOD}

The study was conducted in two phases, namely:

- Phase 1: Data collection and analysis.

- Phase 2: Development of accompaniment guidelines to enhance relationships amongst nurse managers and professional nurses.

\section{Population}

The target population for the study comprised qualified professional nurses with at least two years clinical nursing experience. They were permanent employees of a state hospital who were fluent in English, as this was the language in which the study was conducted.

\section{Sample method}

The sampling method used was purposive. The sample population selection criteria were as follows:

The participants had to:

- be professional nurses permanently employed in an urban state hospital in the Nelson Mandela Metropole;

- have at least two years or more experience as qualified professional nurses; and

- be directly involved with bedside nursing of patients.

Participants were identified by the researcher personally while they were on duty. Participants were asked for their contact details and appointments were made to contact them telephonically. During the subsequent telephone calls the prospective participants were provided with a brief explanation of the study objectives and appointments were made to meet with them personally.

\section{Data collection method}

Data were collected by means of unstructured individual interviews as well as taking of field notes (Creswell, 1994:121). The question posed to all the participants was: "Tell me, how do you experience your professional relationship with your nurse managers?"

The interviews were conducted informally, taped using an audiotape recorder and transcribed verbatim within 48 hours of the interview.

\section{DATA ANALYSIS}

This study employed the eight steps provided by Tesch, as described in Creswell (1994:155), to analyse the data systematically by segmenting it into various categories which formed the basis of the emerging storyline. The researcher made use of the services of an independent coder to verify the results. A consensus discussion was held between the researcher and the independent coder to discuss the results of the data analysis process. The researcher provided the independent coder with a clean set of transcribed interviews, as well as clear instructions for the analysis of data.

\section{TRUSTWORTHINESS}

For the purposes of data verification, the researcher utilised Guba's model of trustworthiness for qualitative research, (Krefting, 1991:214). The four criteria used to ensure trustworthiness were: truth value, applicability, consistency and neutrality, using the following strategies:

- Truth value: Data were gathered through one-on-one interviews using the phenomenological research approach. Peer examination was done by independent colleagues who had experience in the qualitative research method. Leading of participants during the interview sessions was prevented through the application of bracketing. At the end of each interview participants were given the researcher's contact details for use should the need arise.

- Applicability: Results of the study were compared to those of similar studies done previously.

- Consistency: A full description of the data collection and analysis findings of the study were verified through existing literature, other 
relevant research studies, as well as experts in the field of management and in the field of qualitative research.

- Neutrality: Data collection and analysis were free from bias.

\section{ETHICAL CONSIDERATIONS}

The following ethical measures were implemented in this study in order to protect the participants from harm or risk:

- Informed consent: All the relevant health authorities were provided with an application letter requesting permission to do the study. The following information pertaining to the study was included with the application:

- title;

- objectives;

- data collection method to be used;

- sample and sampling method to be used;

- a copy of the consent form to be signed by the participants;

- the names of the supervisor and co-supervisor of the study; and

- ethical considerations to be observed.

Participants were also provided with the same information both verbally and in writing. Data collection only commenced once the necessary permissions were obtained.

- Anonymity and confidentiality: Names of persons and places were not divulged. Audiotapes and scripts were locked away until the study was completed and thereafter destroyed. Participants were selected in a manner that could not arouse the suspicions of colleagues.

- Privacy: Participants had the right to determine the general circumstances under which private information would be shared, as well as the extent to which they would share this information.

- Protection from harm: No invasive procedures were used in this study.

\section{DISCUSSION OF RESULTS OF THE STUDY}

Two main themes with six sub-themes emerged from the data analysis. The two main themes identified were:

- Professional nurses experience a breakdown of their professional relationship with nurse managers.

- Professional nurses experience their expectations related to the work environment as not being met.

The results of the data analysis have been tabulated in Table 1 according to the identified themes, sub-themes and emotional manifestations that reflect the experiences of the participants.

The main focus of this article will be on the discussion of these themes in order to present a clear picture of the experiences of these professional nurses.

\section{THEME 1: PROFESSIONAL NURSES EX- PERIENCE A BREAKDOWN OF THEIR RELATIONSHIP WITH NURSE MANAG- ERS}

During the data analysis phase of this study the researcher identified that professional nurses experience a breakdown in their relationship with their nurse managers. There was a problem of non-engagement between these two nursing categories that resulted in a lack of trust by the professional nurses. For that reason professional nurses expressed feelings of not being guided, supported and/or recognised for their positive contributions by nurse managers, resulting in their disillusionment. Disillusionment, as expressed by the professional nurses, is being further aggravated by noncommunication, or no feedback, from the nurse managers about their patient care activities.

In order to cope with these experiences so that they could focus on patient care, professional nurses tended to resort to various coping mechanisms. Coping, as defined by Kleinke (1991:3), refers to the efforts made by people to manage situations that have been found to be potentially harmful or stressful. Professional nurses used aggression, displacement of the experiences and suppression of the frustration caused by feelings of being let down and ignored by nurse managers as coping mechanisms.

A question that remains to be asked is: "Who initiates interaction/relationship in the professional nurse/nurse manager relationship?" Nurse managers, by virtue of their managerial position and authority, have the mandate to expect cooperation. For this reason they have 
Table 1: Identified themes and sub-themes related to the experiences of professional nurses of their relationship with nurse managers

\begin{tabular}{|c|c|c|}
\hline THEMES & SUB-THEMES & $\begin{array}{l}\text { EMOTIONAL } \\
\text { MANIFESTATIONS }\end{array}$ \\
\hline $\begin{array}{l}\text { 1. Professional nurses } \\
\text { experience a breakdown of } \\
\text { their relationship with nurse } \\
\text { managers }\end{array}$ & $\begin{array}{l}\text { 1.1 Professional nurses } \\
\text { experience themselves as } \\
\text { not being recognised as } \\
\text { persons by nurse managers } \\
1.2 \text { Professional nurses } \\
\text { experience that nurse } \\
\text { managers do not regard } \\
\text { them as competent clinical } \\
\text { practitioners } \\
1.3 \text { Professional nurses } \\
\text { experience their nurse } \\
\text { managers as unprofessional }\end{array}$ & $\begin{array}{l}\text { Anger, frustration, despair, } \\
\text { sadness, loss of hope, pain } \\
\text { and hurt } \\
\text { Hatred, bitterness } \\
\text { Dislike, demotivation }\end{array}$ \\
\hline $\begin{array}{l}\text { 2.Professional nurses } \\
\text { experience their expectations } \\
\text { related to the work } \\
\text { environment as not being } \\
\text { met }\end{array}$ & $\begin{array}{l}\text { 2.1 The resources in the } \\
\text { work environment are } \\
\text { experienced as inadequate } \\
2.2 \text { The support system in } \\
\text { the work environment is } \\
\text { experienced as inadequate } \\
\text { 2.3 The work environment is } \\
\text { experienced as unsafe }\end{array}$ & $\begin{array}{l}\text { Fear, disempowerment } \\
\text { Loneliness, insecurity, } \\
\text { neglect, alienation } \\
\text { Threats, conflicts }\end{array}$ \\
\hline
\end{tabular}

the right to act, or command subordinates to act, in order to achieve the predetermined objectives (Gillies, 1989:372). Nurse managers, therefore, have the responsibility to create and initiate specific behavioural relationships in their nursing units or departments. In this study, professional nurses felt that their nurse managers were not initiating relationships that were sincere and effective with the result that professional nurses felt that they were not being cared for by nurse managers, hence the breakdown in relationships.

The breakdown in the relationship between nurse managers and professional nurses was reflected in the following statement: "... Sometimes you feel there's a gap ... there's no connection".

The experience of the breakdown in the relationship between the professional nurses and the nurse managers was also expressed by professional nurses as coming from the non-involvement of them in the decision-making processes and the lack of communication with them by nurse managers. Communication is a two-way process and feedback completes this cycle (Booyens, 1998:274). A participant described her experience of not being involved in decision-making pro- cesses and not being communicated with, as follows: "... it sort of deprives you of something, it deprives you of the part you are ... a member of this and that you've got the mind and that you can contribute".

\section{Sub-theme 1.1: Professional nurses expe- rience themselves as not being recognised as persons by the nurse man- agers}

The breakdown of relationships of professional nurses with nurse managers manifests, inter alia, in the professional nurses experiencing themselves as not being recognised as individuals or as professional persons: "It makes you feel as if you're being pushed around and not considered as a person".

Nurse managers expect professional nurses to respect the human rights of patients but that same respect is not being afforded to the professional nurses and this experience is having a demotivating effect on them: "... nobody will come and investigate, and will say the client has a right, the client I understand has got a right but at the same time we've also got rights because we are also human beings ...". 
Motivation implies that expectations have been taken into consideration and it is only a sensitive leader/manager who can be successful in the motivation of the subordinates. According to Meiring (1999:4) sensitivity of a leader is described as the extent to which a person is likely to have job relationships that are characterised by mutual trust, respect for subordinates' ideas, regard for their feelings and help with their personal problems. This seems to be lacking in the relationship of the professional nurses with nurse managers, leading to the feeling amongst the professional nurses that they were not regarded as persons by nurse managers: "... for example if I say I was sick there won't be that question, 'How do you feel right now?' ... With me it is very important because it shows that you care ... understand? ... They don't consider my feeling that I was sick, they consider my pair of hands, my hands that were not there. When they talk, they talk of numbers, not individuals, they make calculations and come up with answers ...".

This response implies that professional nurses expect nurse managers to have regard for their feelings and to assist with, and listen to, their personal problems. It also indicates that this expectation is not being met by the nurse managers. The lack of recognition of them as persons by the nurse managers caused the professional nurses to lose trust in the nurse managers. Cohen, Fink, Gadon, Willits and Josefowitz (1992:290) state that a relationship that makes each person feel supported, adequate and worthy will generally lead to mutual feelings of closeness, warmth and trust.

Professional nurses experience themselves as not being trusted to make sound judgements and work independently and competently. Kotzé (1998:12) emphasises that trust is established through awareness of respect and acceptance and the observance of competence.

\section{Sub-theme 1.2: Professional nurses expe- rience that nurse managers do not regard them as competent clinical practitioners}

Participants in this study expressed concern regarding the recognition given to them by the nurse managers for their expertise and experienced themselves as being ignored. This non-recognition by nurse managers makes the professional nurses feel as if they are being regarded as non-professional people. One participant responded as follows: "... you are being told of what should be done. I think we at the floor at the implementation level, we should be involved in some matters because at the end of the day whatever decision that is made affects us in one way or another".

Professional nurses want to experience control of their nursing practice. Professional nurses in South Africa, in the experience of the researcher, are generally confident of their clinical expertise due to their extensive education and training and licensure by the South African Nursing Council and, therefore, can be given this control. Professional nurses expressed concern that acceptance of authority and competence seemed to be one-sided, as if reciprocal recognition of knowledge and skills were not a consideration in the eyes of the nurse managers: "... you are so demotivated most of the time ... like for instance how certain things are handled, you are being told of what should be done. It makes you feel like a worker, not a professional ... a professional person should have an input'.

By virtue of their education and training, and the fact that they are being recognised by a professional body as competent professionals, professional nurses expect both to be respected and for professionalism to be practised by all. Data analysis in this study also revealed that professional nurses experienced an attitude of non-professionalism on the part of their nurse managers.

\section{Sub-theme 1.3: Professional nurses expe- rience their nurse managers as unprofes- sional}

Professionalism depends not only on whether people are licensed to practise within a profession, but also on how well they practise and on their degree of commitment to their profession. Professionalism only becomes a reality when it is observed in one's behaviour. Non-professional behaviour experienced by professional nurses included being undermined, as well as being subjected to displays of arrogance. Some professional nurses described how they were treated with arrogance in times of difficulty: "It happens that they become arrogant ... It is difficult for me to approach them when they're so arrogant ... It is a problem...". 
Professional nurses reported that nurse managers came on duty late at times and were not prepared to assist in nursing care activities: "Another thing is late coming by the supervisor ... you'll find that the supervisor is always late ....".

Searle and Pera (1998:116) mention role-modelling as one of the commitments of professionalism. They state further that, as role models, committed nurses (nurse managers) should evoke a desire in other nurses to follow their professional example. According to the findings of this study, this duty is not being fulfilled by nurse managers. One of the participants said: "... there she comes shouting at you ... you feel bad when the supervisor reprimands you in front of the patients or doctors ... I mean she should be exemplary ...."

Unprofessional behaviour by nurse managers is experienced as disappointing by the participants, as they do not expect such conduct from their leaders. One participant expressed disappointment and disillusionment: "... nurse managers ... do not stick or keep professional secrecy ... I usually feel down, disappointed ... I don't expect you know, such behaviours from professional people".

THEME 2: PROFESSIONAL NURSES EXPERIENCE THEIR EXPECTATIONS RELATED TO THE WORK ENVIRONMENT AS NOT BEING MET AND THUS AFFECTING THEIR RELATIONSHIP WITH NURSE MANAGERS

Participants verbalised that their work environment did not meet their expectations regarding safety, security, support and work resources. Participants in this study voiced disappointment that these expectations were not being met. They view the creation of a conducive work environment as part of the responsibilities of the nurse manager.

\section{Sub-theme 2.1: Resources in the work environment are experienced as inad- equate}

Participants expressed concern about the lack of both human and material resources and the effect of this on the provision of quality nursing care. According to Gillies (1989:515) quality nursing care is the established tar- get of excellence of nursing interventions and actions to ensure that each patient receives the agreed-upon level of care. From the latter statement the researcher concluded that quality nursing care was almost impossible without adequate resources. This is because, amongst other factors, quality care is dependent on available facilities, the number of nurses and the level of motivation. One of the participants commented: “... sometimes you want to open a small window on the P.O.P (plaster of Paris) of a patient instead of removing the whole cast ... you cannot, as there is either no equipment for that, or ... you have to go from ward to ward wasting time before you can do that small procedure ... It leaves you dissatisfied and disempowered as you cannot do anything about it'.

Furthermore, shortage of resources leaves professional nurses embarrassed: "You know with this shortage, I mean food, instruments to work with and linen...you feel so embarrassed ...".

The psychological effects of the shortage of resources on the professional nurses were also worsened by the role played by the local media. Reports published were not easily understandable by the public and this increased the pressure on the professional nurses: “... this whole thing is dehumanising ... because each time you open a newspaper you read about your hospital ...".

This statement was verified by the researcher who collected six newspaper articles written within a two-month period about health issues in the Nelson Mandela Metropole.

\section{Sub-theme 2.2: The support system in the work environment is experienced as inad- equate}

Participants expressed concern about lack of support from their nurse managers. Support and caring is crucial as it provides security and motivation amongst employees and encourages teamwork. Employees work better under the supervision of nurse managers who show consideration towards them and are supportive, fair and just in their treatment of others (Booyens, 1998:698). One participant commented: “... they are supposed to take care of us but this is not happening. You sit with a problem ... Yhaa! Support and motivation 
in this profession, that is something that is lacking ... it's lacking in this caring profession ...".

From the above response the researcher concludes that professional nurses are not receiving the necessary support from their nurse managers. Nurses need to strive constantly to adapt in the work environment, where they find themselves being challenged by all sorts of health dynamics, emotional situations and health care demands. The support is lacking, with the result that there are signs of mistrust and non-cooperation by the professional nurses. This reaction by the professional nurses was predicted by Swansburg and Swansburg (1999:470) who said that "Nurses respect leaders whose judgement is sound and consistent and whose decisions are based on fairness, equity and honesty ... people would much rather follow individuals they can count on, even when they disagree with their viewpoint, than people they agree with but who are inconsistent and shift positions frequently".

Caring and support are essential amongst health professionals, especially stemming from the nurse managers, because it makes calculated risk-taking possible and encourages the professional nurses to develop courage in their becoming (Khoza,1996).

\section{Sub-theme 2.3: The work environment is experienced as unsafe}

One of the management functions is the creation of a therapeutic environment for patient care and a physically and emotionally safe environment for personnel (compare Kotzé, 1998:9). Professional nurses expressed concern about their safety as they experience their work environment as a threatening place where they experience conflict internally amongst personnel and externally as a result of community violence and gangster activities, which often extend into the hospital/health service environment. They also experience insults from patients who, at times, become aggressive. The following response illustrates this experience: "The community we are working for, has no appreciation ... and now they come and swear ... those funny insults ... but nobody ever follow up those incidents ..., for instance, ... there is no treatment in the hospital ... they become, you know, aggressive telling us that 'you are useless' '... and that we are wasting government money by being there".
Listening to responses such as these the researcher concluded that, owing to the unsafe work environment, professional nurses may be experiencing severe psychological stress which could cause conflict in the work environment. Gillies (1989:389) explains that nurses are subject to psychological stress because of the nature of working conditions in hospitals that have become difficult and different from those with which the professional nurse became acquainted as a student.

The caring support by nurse managers that could be demonstrated through the creation and maintaining of a safe work environment is not happening, resulting in unnecessary conflict.

Participants had to create methods of coping and continuing with their work and responsibilities in the work environment and, as a result, became defensive. Reports of the threats from gangsters and insults from aggressive patients are reported as not being given the attention they deserve. Professional nurses reported experiencing actions of favouritism by nurse managers which resulted in conflict amongst professional nurses.

It is obvious that the conflict experienced by participants in this study affected the relationship between them and their nurse managers. Coping mechanisms used to deal with this conflict were not always effective.

\section{SUMMARY OF RESULTS}

As is evident from this discussion, interesting experiences emerged, some of which were consistent with available literature. The two main themes identified were:

- Professional nurses experience a breakdown of their professional relationship with nurse managers.

- Professional nurses experience their expectations related to the work environment as not being met.

Negative emotional experiences that came through very strongly were expressed openly and emphatically by the participants. Professional nurses felt that, as a result of the lack of support of by nurse managers, their needs were not identified. This produced conflicting feelings in the participants and led to conflict between them, their colleagues and the nurse managers. Fortunately the negative effects of these experiences were 
neutralised to a lesser degree through the use of coping strategies.

Even though strong emotional feelings were expressed by the participants, it was interesting to observe positive feelings towards nurse managers outside the work environment on a personal level. Another positive finding was that some of the professional nurses interviewed blamed themselves for some of the negative support and attitudes of the nurse managers. They also understood that not all of the problems had instant solutions and that the nurse managers were also experiencing pressure.

\section{ACCOMPANIMENT GUIDELINES, LIMITA- TIONS AND CONCLUSIONS}

Findings of the study showed a lack of support of professional nurses by nurse managers that resulted in apprehension and conflict in the clinical environment. The presentation of guidelines and recommendations to facilitate support for professional nurses will be based on the principles in the Nursing Accompaniment Theory of WJ Kotzé (1998:9).

\section{Accompaniment guidelines identified to enhance the relationship between profes- sional nurses and their nurse managers}

It is recommended that strategies be considered to enhance the establishment of a relationship of positive and constructive cooperation between professional nurses and nurse managers.

\section{Guidelines identified to assist nurse managers with this relationship in- clude:}

\subsection{Professional nurses experience themselves as not being recognised as persons by nurse managers}

Establish effective unit communication channels.

- Communication channels need to be well developed. Hellriegel, Jackson and Slocum (1999:540) state that without effective communication there is little that can be accomplished by managers. Effective unit communication channels can be estab- lished through convening weekly meetings where face-to-face interactions and discussions can take place. Important considerations in this regard include:

- Clarification of ideas so that subordinates understand the content of discussions and instructions.

- Ensuring that actions support, rather than contradict, ideas and instructions.

- $\quad$ Securing feedback with regard to instructions (Du Toit, Van der Walt, Bayat \& Cheminais, 1998:202).

1.2 Professional nurses experience that nurse managers do not regard them as competent clinical practitioners

Establish a participatory management style.

- Research has proved that participatory management produces high-performance teams and that the most effective leaders are those who have supportive relationships with their team members (Hellriegel, Jackson \& Slocum, 1999:506). The researcher, therefore, recommends the following:

- Including and involving professional nurses in the decision-making process.

- Establishment of formal in-service education programmes and workshops for professional nurses and nurse managers related to teamwork.

- Manage performance appraisal effectively and innovatively.

\subsection{Professional nurses experience their nurse managers as unprofes- sional}

It is recommended that programmes be established to create the opportunity for nurse managers to develop and practise leadership skills. Strategies to be considered are:

- Peer reviewing for identification of needs and conducting of workshops or in-service education sessions.

- Training nurse managers to be effective change agents. 
- Allowing professional nurses to be involved in the change process.

\section{Professional nurses expressed their expectations related to the work environment as inadequate}

\subsection{The resources in the work environ-} ment are experienced as inadequate

- Facilitation of the development of self-empowerment strategies to equip professional nurses to maintain themselves meaningfully and purposefully in the work environment through:

- formation of focus groups where professional nurses can discuss and share opinions on solving the problems;

- encouragement of professional nurses to communicate their need to consult with specialists in the field of self-empowerment; and

- creating opportunities and encouraging professional nurses to attend short courses or programmes to develop and equip them with coping skills, especially those related to the shortage of resources.

- In-service education and workshops on optimal and effective utilisation of resources.

- Promotion of a sense of ownership of material resources in both the professional nurses as well as the nurse managers.

\subsection{The support system in the work envi-} ronment is experienced as inadequate

- Improve patient care skills of professional nurses in the work environment through the use of senior personnel as potential mentors and coaches.

- Prepare nurse managers to be supportive managers by:

- training and encouraging them to create a trust relationship in the work environment that will encourage professional nurses to approach them with their professional needs; and allocating them study leave for the purpose of attending relevant courses and programmes.

\section{LIMITATIONS OF THE STUDY}

Limitations of this study were as follows:

- The language medium used during interviews was English which was not the home language of the participants who were all Xhosa-speaking. Experiences and verbalisation of experiences in the mother tongue could have contributed to richer data for the study.

- The fact that the data reflects the experiences of a sample of professional nurses in one, and not all, public hospitals in the Nelson Mandela Metropole is a limiting factor in the findings of the study.

\section{CONCLUSION}

It is evident from the information gained through experiences shared by participants in this study that there is a breakdown of a professional relationship between professional nurses and nurse managers that requires attention. The fact that the breakdown of a relationship between these two categories must have negative implications for staff commitment, the quality of patient care and nursing service generally, indicates that remedial action is required to improve the relationship between professional nurses and nurse managers.

\section{BIBLIOGRAPHY}

BOOYENS, SW 1998: Dimensions of nursing management. Cape Town: Juta.

COHEN, AR; FINK, SL; GADON, H; WILLITS, RD \& JOSEFOWITZ, N 1992: Effective behaviour in organizations. Boston: Richard.

CRESWELL, JW 1994: Research design : Qualitative and quantitative approaches. London: Sage.

DU TOIT, DF; VAN DER WALT, G; BAYAT, MS \& CHEMINAIS, J 1998: Public administration and management for effective governance. Kenwyn: Juta.

GILLIES, DA 1989: Nursing management. A systems approach. Philadelphia: WB Saunders.

GMEINER, A\& POGGENPOEL, M 1996: Nursing service managers' views on problems they experience in their everyday lives. Part 1 Curationis, 19(1):55-60. 
GORDON, J 1990: Holistic medicine and mental health practice: towards a new synthesis. American Journal of Orthopsychiatry, 60(3):357-370.

HELLRIEGEL, D; JACKSON, SE \& SLOCUM, JR 1999: Management. Cincinnati: South-Western College Publishing.

KHOZA, LB 1996: Caring for the newly qualified professional nurse. Nursing News, October 1996:42-43.

KLEINKE, CL 1991: Coping with life challenges. California: Brookes/ Cole.

KOTZÉ, WJ 1998: An anthropological nursing science: Nursing accompaniment theory. Health SA Gesondheid. 3(3):3-14.

KREFTING, L 1991: Rigor in qualitative research: The assessment of trustworthiness. American Journal of Occupational Therapy, 45(3): 214-222.

MEIRING, MH 1999: Public policy and management programme. (Unpublished lecture notes).

PERA, SA \& VAN TONDER, S 1996: Ethics in nursing practice. Cape Town: Juta.

SEARLE, C \& PERA, SA 1998: Professional practice. Sandton: Heinemann.

SOURIAL, S 1997: An analysis of caring. Journal of Advanced Nursing, 26:1189-1192.

SWANSBURG, RC \& SWANSBURG, RJ 1999: Introductory management and leadership for nurses. London: Jones \& Bartlett. 